\title{
THE EFFECTS OF THREE COMMERCIAL DIETS DIFFERING IN PROTEIN AND ENERGY RATIOS ON PRODUCT QUALITY OF PIKE (ESOX LUCIUS)
}

\author{
B. KuCSKa ${ }^{a *}$, T. Feledi ${ }^{\mathrm{b}}$, Á. AdORJÁN ${ }^{\mathrm{b}}$ and T. MoLnÁR \\ ${ }^{a}$ Department of Aquaculture, Kaposvár University, H-7400 Kaposvár, Guba S. u. 40. Hungary \\ ${ }^{\mathrm{b}}$ Research Institute for Fisheries Aquaculture and Irrigation, Szarvas, Anna-liget 8. Hungary
}

(Received: 9 February 2015; accepted: 20 April 2015)

\begin{abstract}
This study investigated the effects of three different commercial diets on the growth, feed utilization, and product quality of pike (Esox lucius). The first diet had low lipid (12\%) and low protein (37\%) (diet A) content, the second diet had low lipid (12\%) and high protein (52\%) content (diet B), the third diet had higher lipid concentration (15\%) and high protein content (52\%) (diet C). Two hundred and seven pike were stocked in an experimental RAS (Recirculating Aquaculture System) and were fed ad libitum for the duration of the nine week trial. Specific growth rates, feed conversion rates, protein utilization, as well as body composition and somatic indices were calculated. Fish fed with diets B and C had significantly better SGR (Specific Growth Rate) and FCR (Feed Conversion Rate) than fish fed with diet A. The higher dietary lipid concentration does not cause significantly better protein utilization. Moreover, it had a negative effect on the product quality by increasing the body lipid concentration and the visceral fat deposition.
\end{abstract}

Keywords: chemical composition, dietary lipid and protein concentration, feed utilization, fish meat, pike

Thanks to advancements in rearing technologies, it is now possible to conduct intensive rearing of pike in RAS (Recirculating Aquaculture Systems) using commercial, formulated feed (Wolnicki \& Górny, 1997; KuCSKa et al., 2005; Szczepkowski, 2009; SzczepKowski et al., 2012). Commercial diets currently used for pike are developed for other species including trout, catfish, sturgeon, etc. These diets are greatly differing in protein and energy content, which can influence the production parameters as well as the product quality. The balance between digestible protein (DP) and digestible energy (DE) in the diet is a key factor. Decreasing dietary DP/DE ratio results in an increase of protein conservation. The amino acids are not catabolised for energy, and are conserved in the body at a greater ratio. However, increasing the concentration of dietary lipid can increase lipid concentration in the whole body of the fish (Shearer, 1994; Rasmussen, 2001; Molnár et al., 2012), which can have many implications on fish product quality. The higher energy intake can increase the VSI (visceral somatic index) as well as the viscera lipid concentration (HiLlestAD et al., 1998; RASmussen et al., 2000), which is discarded as a by-product during processing. Another disadvantage is the potential for an increased rate of lipid oxidation in feed and in fish, which could negatively affect nutritional qualities and the taste of the fillets (CHAIYAPECHARA et al., 2003). Our previous study demonstrated that optimal lipid content in feed for pike is around $12 \% \mathrm{CF}$ (crude fat) in case of $45 \% \mathrm{CP}$ (crude protein) content (Molnár et al., 2012). Currently there are recommendations for minimum protein demand for North American relative species

\footnotetext{
* To whom correspondence should be addressed.
} Phone: +36-82-505 800; e-mail: kucska.balazs@ke.hu 
muskellunge (Esox masquinongy) (CP 37\%) and tiger muskellunge, its hybrid with pike (E. masquinongy $\times$ E. lucius) $(45 \%)$ (BRECKA et al., 1995), but it has not yet been determined in the case of pike. Moreover, the effect of different protein and energy ratios in feeds has not been studied yet. The aim of the recent study was to investigate the effects of three different commercial diets, where two of them contained equal lipid content $(12 \% \mathrm{CF})$ and had low $(37 \% \mathrm{CP})$ and high (CP 52\%) protein content, and a third commercial feed with increased lipid concentration $(15 \% \mathrm{CF})$ and equal high protein content (CP 52\%), on the feed utilization and product quality of pike.

\section{Materials and methods}

\subsection{Rearing conditions}

The experiment was carried out with 207 pike $\left(\mathrm{w}_{0}: 76.1 \pm 13.4 \mathrm{~g}\right)$ grown in an experimental RAS system and fed exclusively on a dry diet. The pike were stocked in $9 \times 300$ litre plastic tanks (23 fish each). The tanks were linked to a RAS system (settling compartment, biological filter and sump) run with aerated tap water $(\mathrm{pH} 8.3 ; 13 \mathrm{dGH}$ (degrees of general hardness): 13; TAN (total ammonia nitrogen) $<0.3 \mathrm{ppm} ; \mathrm{NO}_{2}-\mathrm{N}<0.1 \mathrm{ppm} ; \mathrm{NO}_{3}-\mathrm{N}<1 \mathrm{ppm}$ ). The dissolved oxygen was kept close to $100 \%$ saturation. The water temperature was $20.5 \pm 1.0^{\circ} \mathrm{C}$, the flow rates were set to achieve a water exchange of $200 \% \operatorname{tank}^{-1} \mathrm{~h}^{-1}$. During the experiment $14 \mathrm{~h} \mathrm{light} / 10 \mathrm{~h}$ dark cycle was used. The duration of the trial was 9 weeks.

\subsection{Experimental setup}

The fish were randomly assigned into nine groups (three diets in triplicates). The experimental diets were commercial diets produced by ALLER-AQuA, see Table 1. (Where diet A developed for carp/tilapia, diet B for sturgeon broodstock, diet C for sturgeon grower.)

Table 1. Composition of the experimental diets

\begin{tabular}{lllll}
\hline Experimental diet & & $\mathrm{A}$ & $\mathrm{B}$ & $\mathrm{C}$ \\
\hline Crude protein & $\%$ & 37 & 52 & 52 \\
Crude fat & $\%$ & 12 & 12 & 15 \\
NFE & $\%$ & 34.7 & 17.9 & 13.1 \\
Gross energy & $\mathrm{KJ} \mathrm{g}^{-1}$ & 19.9 & 20.3 & 20.8 \\
Protein/energy & & 18.6 & 25.6 & 25 \\
\hline
\end{tabular}

NFE: Nitrogen Free Extract (data are declared by Aller-Aqua Poland)

Fish were fed two to three times a day by hand until visual satiation was achieved. Any uneaten feed was siphoned out and the remained pellets were counted and taken into account when the exact feed intakes were calculated. 


\subsection{Data collection and statistical analysis}

All fish were measured individually at the beginning and end of the trial (Sartorius scales $\pm 0.1 \mathrm{~g}$ ) and in groups during the weekly measurements (considering animal welfare fish were not captured individually). At the end of the trial, 5 randomly selected individuals from each treatment were over anaesthetized with clove oil. After measuring the standard length and bodyweight, fish were dissected and the viscera and liver were measured with an accuracy of $0.01 \mathrm{~g}$ (Sartorius scales). The bodies were homogenized for biochemical composition analysis. Dry matter content was determined after drying samples in a vacuum oven at $50{ }^{\circ} \mathrm{C}$ (Thermocenter, Salvis Lab, Switzerland) and a vacuum of $13.3 \mathrm{kPa}$, using anhydrous calcium chloride as the drying agent. After $16 \mathrm{~h}$, the vacuum was changed to $0.2 \mathrm{kPa}$ and the samples were weighed every $4 \mathrm{~h}$ until they reached constant weight. Nitrogen content was determined in the fresh samples by Kjeldahl analysis according to ISO 5983 (ISO, 1997). The crude fat content was determined by extraction of freeze-dried samples with petroleum-ether and drying the extract at $103{ }^{\circ} \mathrm{C}$ to a constant weight according to ISO 6492 (ISO, 1985).

The following indices were calculated:

Survival rate $=$ final number of individuals/initial number of individuals $\times 100(\%)$

SGR (Specific Growth Rate) $=100\left(\mathrm{Ln} \mathrm{W}_{\text {final }}-\mathrm{Ln} \mathrm{W}_{\text {initial }}\right) \mathrm{t}^{-1}$

PER (Protein Efficiency Ratio)=fish biomass increment $(\mathrm{g}) \times$ food protein consumption $(\mathrm{g})^{-1}$

FCR $($ Feed Conversion Rate $)=$ total feed consumption $(\mathrm{g}) \times$ fish biomass increment $(\mathrm{g})^{-1}$

Total feed intake $=$ daily feed intake $\times$ number of days $(\mathrm{g})$

Total protein intake $=$ total feed intake $\times$ protein ratio of the feed $(\mathrm{g})$

Total protein intake $=$ total feed intake $\times$ energy content of the feed $(\mathrm{KJ})$

VSI $($ Visceral Somatic Index $)=\mathrm{V} / \mathrm{W} \times 100(\%)$

HSI (Hepatosomatic Index $)=\mathrm{H} / \mathrm{W} \times 100(\%)$

where,

W: bodyweight (g); t: duration of the trial in days; V: weight of viscera (g); H: weight of liver (g)

Statistical analyses were carried out with SPSS 13.0 for Windows. The analysis of variance (one-way ANOVA) procedure was used to test the main effects. Treatment means were compared using alpha of 0.05 for significance in Tukey's post-hoc test. The relationship between protein energy ratio and FCR or PER was estimated with linear regression.

\subsection{Ethical issues}

The experiment was approved by the Animal Experimentation Ethics Committee of the Research Institute of Fisheries Aquaculture and Irrigation.

\section{Results and discussion}

\subsection{Growth and survival}

The fish fed with diet B $(134.4 \pm 20.7 \mathrm{~g})$ and C $(130.6 \pm 26.3 \mathrm{~g})$ obtained higher body weight than fish fed with diet A $(96.4 \pm 21.4 \mathrm{~g})$. These differences can also be seen in the Specific Growth Rate (SGR) values (Table 2). The survival rates were around $90 \%$ and did not differ significantly ( $86.9 \pm 11.5 \%$ for $\operatorname{diet} \mathrm{A}$ and $91.3 \pm 4.3 \%$ for $\operatorname{diet} \mathrm{B}$ and $\mathrm{C}$ ) (ANOVA $\mathrm{P}<0.01$ ). 


\subsection{Feed intake and feed utilization}

The total feed and energy intake did not differ significantly ( $\mathrm{P}<0.05$ ANOVA), however, the protein intake of the group fed with diet A was $40 \%$ lower than for the other groups (Table 2). Food conversion ratio FCR values in the groups fed $\mathrm{B}$ and $\mathrm{C}$ were similar, but diet $\mathrm{A}$ resulted in a 2.5 times worse feed conversion ratio. Protein efficiency ratio showed similar tendencies, the group fed diet A differed significantly from the other two groups. The relationship between the protein and energy ratios in the experimental diets and the feed conversion and protein efficiency ratios measured in pike are shown in Figure 1. Both parameters had a strong correlation with the protein energy ratio in the diet, and the relationship could be characterized by linear regression.

Table 2. Growth and production parameters of pike in the experiment

\begin{tabular}{lcccc}
\hline Experimental diet & $\mathrm{A}$ & $\mathrm{B}$ & $\mathrm{C}$ & \multicolumn{1}{c}{ P value } \\
\hline Survival (\%) & $86.9 \pm 11.5$ & $91.3 \pm 4.3$ & $91.3 \pm 4.3$ & 0.01 \\
Final weight (g) & $96.4 \pm 21.4$ & $134.4 \pm 20.7$ & $130.6 \pm 26.3$ & 0.01 \\
SGR (\%/day) & $0.37 \pm 0.11^{\mathrm{a}}$ & $0.88 \pm 0.06^{\mathrm{b}}$ & $0.86 \pm 0.08^{\mathrm{b}}$ & 0.001 \\
Total protein intake (g) & $367.6 \pm 58.6^{\mathrm{a}}$ & $574.3 \pm 92.9^{\mathrm{b}}$ & $602.3 \pm 25.9^{\mathrm{b}}$ & 0.011 \\
Total energy intake (g) & $20265 \pm 3122$ & $22418 \pm 1197$ & $24093 \pm 3718$ & Ns. \\
FCR ( $\left.\mathrm{g} \mathrm{g}^{-1}\right)$ & $2.53 \pm 0.45^{\mathrm{a}}$ & $0.97 \pm 0.01^{\mathrm{b}}$ & $0.97 \pm 0.01^{\mathrm{b}}$ & 0.001 \\
PER $\left(\mathrm{g} \mathrm{g}^{-1}\right)$ & $1.08 \pm 0.17^{\mathrm{a}}$ & $2.02 \pm 0.34^{\mathrm{b}}$ & $1.97 \pm 0.03^{\mathrm{b}}$ & 0.004 \\
\hline
\end{tabular}

FCR: feed conversion rate; SGR: specific growth rate; PER: protein efficiency ratio; different letters means significant differences by ANOVA

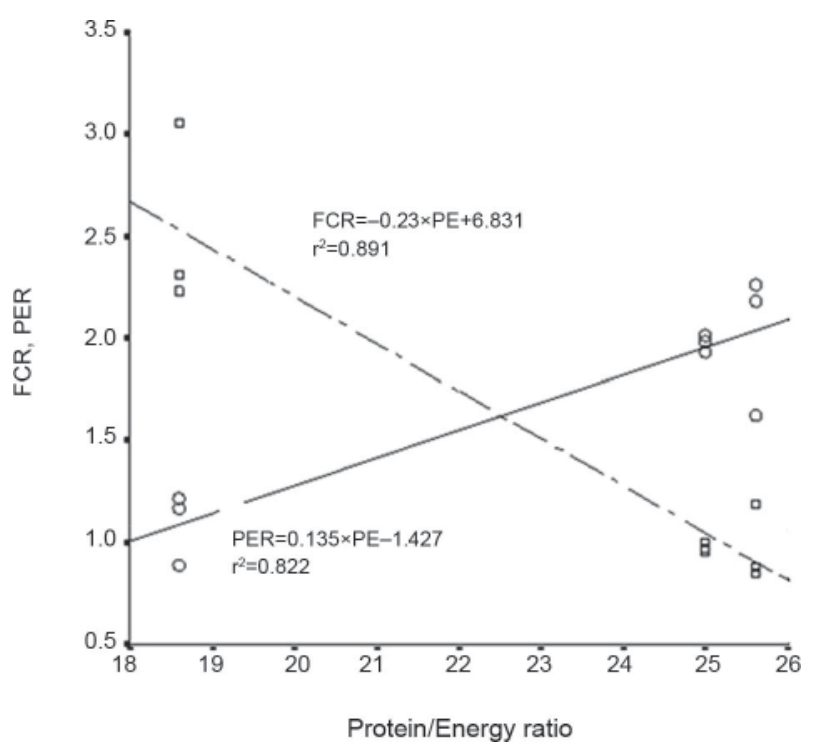

Fig. 1. Relationships between the protein and energy ratio in the experimental diets and feed conversion, $\square$ : FCR; feed conversion rate; $\bigcirc$ : PER; protein efficiency ratio 
Fish fed with diet B accumulated less fat, which can be seen in the body lipid content and also in the Viscera Somatic Index (VSI) shown in Table 3.

Table 3. Body composition data of the fish in the different groups

\begin{tabular}{lcccc}
\hline & $\mathrm{A}$ & $\mathrm{B}$ & $\mathrm{C}$ & \multicolumn{2}{c}{ P value } \\
\hline Moisture (\%) & $71.16 \pm 0.79$ & $72.02 \pm 0.97$ & $70.84 \pm 0.86$ & Ns \\
Lipid content (\%) & $6.6 \pm 0.27^{\mathrm{a}}$ & $5.14 \pm 0.68^{\mathrm{b}}$ & $6.68 \pm 0.37^{\mathrm{a}}$ & $<0.05$ \\
Protein content (\%) & $18.54 \pm 0.78$ & $18.8 \pm 0.59$ & $18.36 \pm 0.32$ & Ns. \\
HSI (\%) & $3.24 \pm 0.86$ & $2.72 \pm 0.53$ & $2.65 \pm 0.91$ & Ns. \\
VSI (\%) & $5.57 \pm 0.66^{\mathrm{ab}}$ & $5.81 \pm 0.84^{\mathrm{b}}$ & $4.42 \pm 0.78^{\mathrm{a}}$ & $<0.05$ \\
\hline
\end{tabular}

HIS: hepatosomatic index; VSI: visceral somatic index; different letters means significant differences by ANOVA

\subsection{Growth and feed utilization}

KozŁOWSKI and co-workers (2012) reported that $0.8 \%$ of the fish biomass feeding rate is optimal for the same sized pike fingerlings using dry feed with $45 \%$ protein and $22 \%$ fat. The ad libitum feeding resulted in a higher average daily feeding ratio in the present study ranging between 1.17 and $1.19 \%$ of the fish biomass. However, this higher rate resulted in a better $\mathrm{SGR}$ in the B and C diet groups and similar or better PER value and much better FCR compared to data published by KozŁowSKI and co-workers (2012) $(0.76 \%$ /day SGR, 1.85 PER and $1.32 \mathrm{~g} / \mathrm{g}$ FCR) and MolnÁR and co-workers (2012) (1.56 PER and $1.47 \mathrm{~g} / \mathrm{g}$ FCR). The relationship between the protein energy ratio and FCR (Fig. 1) suggests that further increments in the protein level of the diet will not result in better feed conversion, as its value is below $1 \mathrm{~g} / \mathrm{g}$ and the extrapolation of the regression could not be realized in practice.

\subsection{Protein requirements}

Pike fed with higher protein (CP 52\%) and lower (CF 12\%) or higher (CF 15\%) fat content diet (diet $\mathrm{B}$ and $\mathrm{C}$ ) grew better, and had a better feed conversion ratio than fish fed with a lower protein (CP 37\%) and fat content (CF 12\%) diet (diet A). This could probably be because of an inadequate protein intake, which was significantly less in case of the fish with $\operatorname{diet} \mathrm{A}$, while there were no significant differences between the groups in energy intake. According to these results, pike probably need higher protein content in feed than muskellunge or tiger muskellunge, where the minimum satisfactory protein level is CP $37 \%$ and CP $45 \%$, respectively, as described by BRECKA and co-workers (1995).

\subsection{Optimal Protein / Energy ratio}

Fish are known to utilize protein preferentially to lipid or saccharides as an energy source. Therefore, it is important from a nutritional, environmental, and economic point of view to improve protein utilization for tissue synthesis rather than for energy purposes (PERES \& Olivia-Teles, 1999). The increase of DE (Digestible Energy) content of fish diets until a certain point, by lipid supplementation, has been shown to have a protein sparing effect, therefore reducing nitrogen losses to the environment (CHO \& KAUSHIK, 1990). According to our results, increasing the lipid content from CF $12 \%$ to CF $15 \%$ did not improve the protein 
utilization, and there were no differences in SGR and FCR values either. The highest Protein / Energy ratio in feed (diet B with 25.6) gave the best results. Moreover, the increment of the dietary energy content resulted in $1 \%$ extra lipid content in the body and significantly higher $(+1.4 \%)$ VSI.

\subsection{Product quality}

Pike meat can be categorized as lean meat. KUCSKA and co-workers (2006) and JANKOwSKA and co-workers (2008) demonstrated that dry food feeding induces higher fillet lipid content (approximately 2.4\%) and the accumulation of abdominal fat (4.4\%) in cultured fish compared to wild specimens $(0.19-1.19 \%)$. This unfavourable tendency was confirmed by MoLNÁr and co-workers (2012) reporting on significantly increasing body lipid content coupling with constant fillet lipid content as a result of feeding a diet with $16 \%$ fat level. These data suggest that commercial diets with high protein energy ratios and lipid levels below $12 \%$ could fulfil the demand for pike to produce better quality fish meat.

\section{Conclusions}

The recommended commercial diet for pike should have a high protein (around 52\% CP) and low fat content (around 12\% CF). Lower protein concentration can decrease the growth and feed utilization. Higher energy intake through increasing the dietary lipid concentration does not cause better protein utilization. Moreover, it can have negative effects on the product quality by increasing the body lipid concentration and the visceral fat deposition. The optimal protein / energy ratio in the feed should be at least 25 .

\section{List of abbreviations}

CF: crude fat; CP: crude protein; DE: digestible energy; DP: digestible protein; dGH: degrees of general hardness; FCR: feed conversion rate; HSI: hepatosomatic index; NFE: nitrogen free extract, PER: protein efficiency ratio; RAS: recirculating aquaculture system; SGR: specific growth rate; TAN: total ammonium nitrogen; VSI: visceral somatic index

This work was supported by the Hungarian Scientific Research Fund (OTKA pd84289).

\section{References}

Aller-Aqua Poland: http://www.aller-aqua.pl/(last accessed: 20. April 2015)

Brecka, B.J., Kohler, C.C. \& WaHL, D.H. (1995): Effects of dietary protein concentration on growth, survival, and body composition of muskellunge Esox musquinongy and tiger muskellunge Esox masquinongy $\times$ E. lucius fingerlings. J. World Aquacult. Soc., 26, 416-425.

Chaiyapechara, S., Casten, M.T., Hardy, R.W. \& Dong, F.M. (2003): Fish performance, fillet characteristics, and health assessment index of rainbow trout (Oncorhynchus mykiss) fed diets containing adequate and high concentrations of lipid and vitamin E. Aquaculture, 219, 715-738.

Cho, C.Y. \& Kaushik, S.J. (1990): Nutritional energetic in fish: energy and protein utilization in rainbow trout (Salmo gairdneri). World Rev. Nutr. Diet, 61, 132-172.

Hillestad, M., Johnsen, F., Austreng, E. \& Asgard, T. (1998): Long-term effects of dietary fat level and feeding rate on growth, feed utilization and carcass quality of Atlantic salmon. Aquacult. Nutr., 4, 89-97. 
ISO (1985): Animal feeding stuffs. Determination of fat content. ISO 6492. International Organization for Standardization

ISO (1997): Animal feeding stuffs. Determination of nitrogen content and calculation of crude protein content Kjeldahl method. ISO 5983. International Organization for Standardization

Jankowska, B., Zakes, Z., Zmijewski, T. \& Szczepkowski, M. (2008): Fatty acid composition of wild and cultured northern pike (Esox lucius). J. Appl. Ichthyol., 24, 196-201.

KozŁowski, M., Szczepkowski, M., Piotrowska, I., Wunderlich, K. \& Szczepkowska, B. (2012): Impact of feed ration on growth, feed conversion, and variation in body weights of juvenile pike, Esox lucius L., reared in a recirculating aquaculture system. Arch. Pol. Fish., 20, 145-152.

Kucska, B., Müller, T., SÁri, J., Bódis, M. \& Bercsényi, M. (2005): Successful growth of pike (Esox lucius) on pellet at artificial condition. Aquaculture, 246, 227-230.

Kucska, B., Pál, L., Müller, T., Bódis, M., Bartos, Á., Wágner, L., Husvéth, F. \& Bercsényi, M. (2006): Changing of fat content and fatty acid profile of reared pike (Esox lucius) fed two different diets. Aquac. Res., 37, 96101.

Molnár, T., Kucska, B., Szabó, A., Biró, J., Bercsényi, M. \& Hancz, Cs. (2012): Effect of graded dietary fish oil supplementation on body composition and fillet fatty acid composition of pike (Esox lucius L.). Acta Alimentaria, 41, 86-93.

Peres, H. \& Oliva-Teles, A. (1999): Effect of dietary lipid level on growth performance and feed utilization by European sea bass juveniles (Dicentrarchus labrax). Aquaculture, 179, 325-334.

RASMUSSEN, R.S. (2001): Quality of farmed salmonids with emphasis on proximate composition, yield and sensory characteristics. Aquac. Res., 32, 767-786.

Rasmussen, R.S., Ostenfeld, T.H., Ronsholdt, B. \& McLean, E. (2000): Manipulation of end-product quality of rainbow trout with finishing diets. Aquacult. Nutr., 6, 17-23.

SHEARER, K.D. (1994): Factors affecting the proximate composition of cultured fishes with emphasis on salmonids. Aquaculture, 119, 63-68.

SzczepKowsKi, M. (2009): Impact of selected abiotic and biotic factors on the result of rearing juvenile stages of Northern pike (Esox lucius L.) in recirculating systems. Arch. Pol. Fish., 17, 107-147.

Szczeprowski, M., Zakes, Z., Kapusta, A., Sczcepkowska, B., Hopko, M., Jarmolowicz, S., Kowalska, A., Kozlowski, M., PARTYKa, K., PiotrowsKa, I. \& Wunderlich, K. (2012): Growth and survival in earthen ponds of different size juvenile pike reared in recirculating aquaculture systems. Arch. Pol. Fish., 20, 267-274.

WOLNICKI, J. \& GóRNY, W. (1997): Effects of commercial dry diets and water temperature on growth survival of Northern pike Esox lucius L., larvae. Pol. Arch. Hydrobiol., 44, 377-383. 